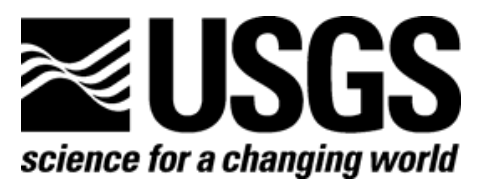

This report was produced in cooperation with South Carolina Sea Grant Consortium

\title{
Geologic Framework Studies of South Carolina's Long Bay from Little River Inlet to Winyah Bay, 1999 - 2003: Geospatial Data Release
}

By W.E. Baldwin, J.F. Denny, W.C. Schwab, P.T. Gayes, R. Morton, and N.W. Driscoll

Open-File Report 2005-1346 


\title{
U.S. Department of the Interior DIRK KEMPTHORNE, Secretary
}

\author{
U.S. Geological Survey \\ Mark D. Myers, Director
}

U.S. Geological Survey, Reston, Virginia 2007

Revised and reprinted: 2007

For product and ordering information:

World Wide Web: http://www.usgs.gov/pubprod

Telephone: 1-888-ASK-USGS

For more information on the USGS—the Federal source for science about the Earth, its natural and living resources, natural hazards, and the environment:

World Wide Web: http://www.usgs.gov

Telephone: 1-888-ASK-USGS

Suggested citation:

Baldwin, W.E., Denny, J.F., Schwab, W.C., Gayes, P.T., Morton, R., and Driscoll, N.W., 2006, Geologic Framework Studies of South Carolina's Long Bay from Little River Inlet to Winyah Bay, 1999 - 2003: Geospatial Data Release: U.S. Geological Survey Open-File Report 2005-1346, DVD-ROM. [Revised 2007]

Any use of trade, product, or firm names is for descriptive purposes only and does not imply endorsement by the U.S. Government.

Although this report is in the public domain, permission must be secured from the individual copyright owners to reproduce any copyrighted material contained within this report. 


\section{Contents}

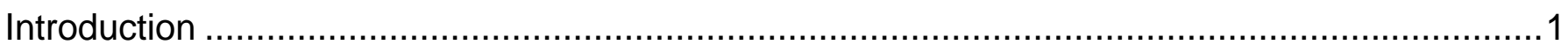

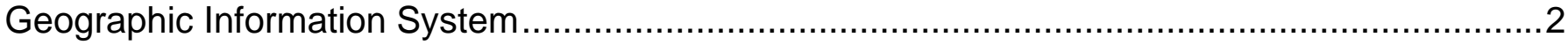

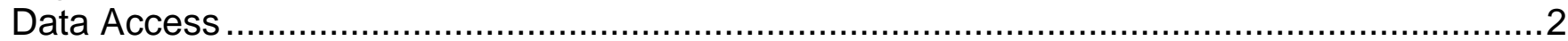

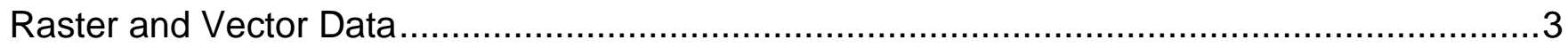

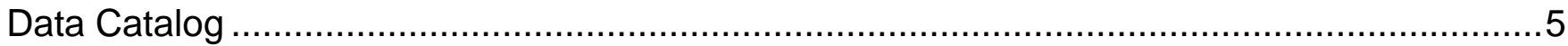

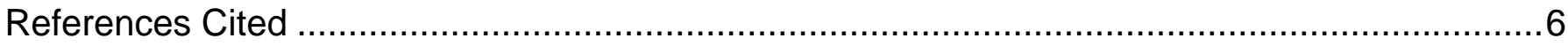

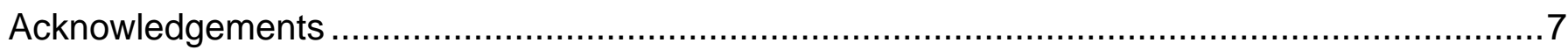

\section{Figures}

Figure1. Map showing the location of the survey area offshore of South carolina between Little River Inelt to thenorth and Winyah Bay to the south. Geophysical tracklines and sample

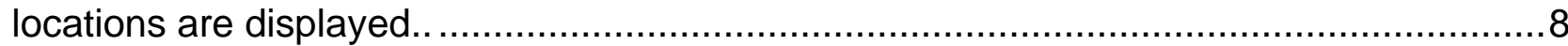

\section{Tables}

Table1. Data Catalog.

\section{Conversion Factors}

Inch/Pound to SI

\begin{tabular}{lll}
\hline \multicolumn{1}{c}{ Multiply } & \multicolumn{1}{c}{ By } & \multicolumn{1}{c}{ To obtain } \\
\hline Length & & \\
\hline foot (ft) & 0.3048 & meter $(\mathrm{m})$ \\
mile (mi) & 1.609 & kilometer $(\mathrm{km})$ \\
mile, nautical (nmi) & 1.852 & kilometer $(\mathrm{km})$ \\
yard (yd) & 0.9144 & meter $(\mathrm{m})$ \\
\hline
\end{tabular}

Vertical coordinate information is referenced to the Mean Lower Low Water (MLLW). Horizontal coordinate information is referenced to WGS84. 


\title{
Geologic Framework Studies of South Carolina's Long Bay from Little River Inlet to Winyah Bay, 1999 - 2003: Geospatial Data Release
}

\author{
By W.E. Baldwin ${ }^{1}$, J.F. Denny ${ }^{1}$, W.C. Schwab ${ }^{1}$, P.T. Gayes ${ }^{2}$, R.A. Morton ${ }^{3}$, N.W. \\ Driscoll $^{4}$
}

\section{Introduction}

The northern South Carolina coast is a heavily developed region that supports a thriving tourism industry, large local populations and extensive infrastructure (Figure 1). The economic stability of the region is closely tied to the health of its beaches, primarily in providing support for local tourism and protection from storm events. Despite relatively low long-term shoreline erosion rates, and the implied stability of the beaches, the economic impact of storm events to coastal communities has been costly. For example, Hurricane Hugo made landfall on the central South Carolina coast in 1989. High winds and storm surge inflicted roughly $\$ 6$ billion in property loss and damages, and remains the costliest storm event in South Carolina history. Localized erosion, commonly occurring around tidal inlets and erosion "hot spots", has also proved costly. Construction and maintenance of hard structures and beach nourishment, designed to mitigate the effects of erosion, have become annual or multi-annual expenditures. Providing a better understanding of the physical processes controlling coastal erosion and shoreline change will allow for more effective management of coastal resources.

In 1999, the U.S. Geological Survey (USGS), in partnership with the South Carolina Sea Grant Consortium (SCSGC), began a study to investigate inner continental shelf and shoreface processes. The objectives of the USGS/SCSGC cooperative program are: 1) to provide a regional synthesis of the shallow geologic framework underlying the shoreface and inner continental shelf, and define its role in coastal evolution and modern beach behavior; 2) to identify and model the physical processes affecting coastal ocean circulation and sediment transport, and define their role in shaping the modern shoreline; and 3) to identify sediment sources and transport pathways, leading to construction of a regional sediment budget.

This report contains the geospatial data used to define the geologic framework offshore of the northern South Carolina coast. The digital data presented herein accompany USGS Open-File

\footnotetext{
${ }^{1}$ USGS, Woods Hole Science Center, Woods Hole, Massachusetts

${ }^{2}$ Coastal Carolina University, Center for Marine and Wetland Studies, Conway, South Carolina

${ }^{3}$ USGS, Center for Coastal and Watershed Studies, St. Petersburg, Florida

${ }^{4}$ Scripps Institution of Oceanography, University of San Diego, San Diego, California
} 
Reports 2004-1013 and 2005-1346, which describe the stratigraphic framework and modern sediment distribution within Long Bay, respectively. Direct on-line links to these publications are available within the references. Additional links to other publications and websites are also available within the reference section.

\section{Geographic Information System}

\section{Data Access}

The spatial data on this DVD are delivered in two different forms: vector and raster data.

All raster and vector data are stored within an ArcGIS map document OFR_2005-1346.mxd. Refer to Section 2 (Raster and Vector Data) below for more details on where they are located on the DVD.

\section{Projection:}

Raster data: Universal Transverse Mercator (UTM) Meters, Zone 17, WGS84 Datum.

Vector data: Geographic Coordinate System, WGS84 Datum

\section{Viewing the data:}

The data can be accessed in a number of different ways depending on software availability.

ArcGIS 9.0 or higher : spatial analyst extension required in order to view and manipulate all data

ArcView 3.x : spatial analyst extension required in order to view and manipulate all data

\section{ArcGIS 9.0 or higher:}

Copy the following folder OFR_2005_1346/ArcGIS to a local computer and open the ArcMap document OFR_2005-1346.mxd. The ArcMap document is saved with relative links. Thus, as long as the sub-folders remain under the parent directory (ArcGIS) there is no need to change drive letters or pathways. The ArcGIS map document can also be read directly from the DVD (read-only mode) by opening OFR_2005-1346.mxd.

Requirements: Approximately 1 gigabyte of free space is needed in order to copy the data to a local drive.

\section{ArcView 3.x:}

The data can be viewed using ArcView 3.x and the spatial analyst extension.

\section{Data Download:}

Raster and vector data are stored and compressed within zip files in order to facilitate downloads. WinZip files are linked within the Data Catalog. See below for specific download instructions (see Data Catalog).

Raster grids are stored as ASCII raster files with associated metadata in the compressed zip document. The ASCII raster files can be easily converted to ESRI grid format in either ArcView 
with spatial analyst extension (Import Data Source: ASCII Raster) or ArcGIS with spatial analyst extension (ASCII to Raster). Vector data are stored as shapefiles within the zip document.

If WinZip is not currently installed on the local system, go to WinZip (www.winzip.com) to download the latest version of the WinZip utility.

\section{Raster and Vector Data}

This section describes the location of the raster and vector data. Raster and vector data are stored as grids, image files, or shapefiles.

Grid: ESRI binary raster data format Image: Tagged Information File Format TIFF

Shapefile: ESRI file format for point, line or polygon vector data.

Layer File: Symbology for individual shapefiles for use within ArcGIS

\section{ArcGIS folder}

This folder contains...

\section{Bathy}

bathy_grd - Grid: Bathymetry

bathy_hillsh - Grid: Shaded relief bathymetry

con_1m.shp - Shapefile: bathymetric contours at 1 meter interval

Bathymetry.lyr - Layer File: symbology for bathymetric grid (bathy_grd)

\section{Mosaic}

mosaic.tif - Image: Sidescan-sonar Mosaic TIFF format

mosaic_comp.sid - Image: Sidescan-sonar Mosaic compressed MrSID format

NGDC- (National Geophysical Data Center)

ngdc_crm.tif - Image: NGDC Coastal Relief Model

\section{Onshore}

boreholes.shp - Shapefile: Locations of 158 boreholes located onshore

boreholes.lyr - Layer File: Symbology for boreholes (boreholes.shp)

gshydd.shp - Shapefile: South Carolina Hydrography

gshydd.lyr - Layer File: Symbology for hydrography (gshydd.shp)

onshore_con.shp - Shapefile: Onshore contours representing the base of the Quaternary section

onshore_con.lyr - Layer File: Symbology for onshore contours (onshore_con.shp) 
rotasonic.shp - Shapefile: Locations and depth of penetration of eight rotasonic boreholes

rotasonic.lyr - Layer File: Symbology for onshore boreholes (rotasonic.shp)

\section{Samples}

grabs.shp - Shapefile: Location and textural information of 722 grab samples

grabs.lyr - Layer File: Symbology for grab samples (grabs.shp)

grainsize_poly.shp - Shapefile: Polygons outlining grain size distribution offshore of the Grand Strand

grainsize_poly.lyr - Layer File: symbology for grain size distribution (grainsize.shp)

\section{Seisimag}

This folder contains JPEG images of seismic-reflection profiles. These images are "hotlinked" to the geophysical tracklines within the ArcMap Document OFR-2005-1346.mxd. Sub-folders within the seisimag directory are organized by cruise number; defined by calendar year (of data collection) and individual cruise ID (e.g. 00014 [2 Digit YR, 3 Digit Cruise ID]).

Using 'HotLink’ with ArcGIS 9.0 or higher:

In order to 'hotlink' to the seismic images, the seismic tracklines must be selected within the Table of Contents. The hotlink feature (lightning bolt) within the Tools Menu can then be used to display the seismic images associated with an individual trackline.

Open OFR_2005_1346.mxd

Select either Boomer Tracklines or Chirp Tracklines under 'TrackLines’ within the Table of Contents

Select the lightning bolt tool and click on an individual trackline to view an image of the seismic data

\section{Seismic_srf}

paleoch_grd - Grid: Elevation of paleochannel unconformities paleoch_grd.lyr - Layer File: Symbology for paleochannels (paleoch_grd)

sedthick_grd - Grid: Thickness of Holocene (modern) sediment sedthick_grd.lyr - Layer File: Symbology for Holocene sediment thickness (sedthick_grd) transgr_grd - Grid: Elevation of the regional transgressive unconformity transgr_grd.lyr - Layer File: Symbology for transgressive unconformity (transgr_grd)

\section{Sf_env}

ridge_crests.shp - Shapefile: Location of the crests of low-relief ridges ridge_crests.lyr - Layer File: Symbology for ridge crests (ridge_crests.shp) 
seafloorenv.shp - Shapefile: Polygons outlining the sea floor environments

seafloorenv.lyr - Layer File: symbology for sea-floor environments (seafloorenv.shp)

\section{Surficial_geo}

surf_geol.shp - Shapefile: Polygons outline the geologic units exposed at the sea floor surf_geol.lyr - Layer File: symbology for surficial geology (surf_geol.shp)

\section{Tracklines}

** Within OFR_2005-1346.mxd: Seismic-reflection tracklines are hotlinked to JPGs stored within the seisimag/ directory. $* *$

bathy_trk.shp - Shapefile: Swath bathymetric tracklines

bathy_trk.lyr - Layer File: Symbology for bathymetric tracklines (bathy_trk.shp)

boomer_sht.shp - Shapefile: Shot points for boomer data

boomer_sht.lyr - Layer File: Symbology for boomer shot points (boomer_sht.shp)

boomer_trk.shp - Shapefile: Boomer (seismic-reflection system) tracklines

boomer_trk.lyr - Layer File: Symbology for boomer tracklines (boomer_trk.shp)

chirp_sht.shp - Shapefile: Shot points for chirp data

chirp_sht.lyr - Layer File: Symbology for chirp tracklines (chirp_sht.shp)

chirp_trk.shp - Shapefile: Chirp (seismic-reflection system) tracklines

chirp_trk.lyr - Layer File: Symbology for chirp tracklines (chirp_trk.shp)

sonar_trk.shp - Shapefile: Sidescan-sonar tracklines

Sonar_trk.lyr - Layer File: Symbology for sidescan-sonar tracklines (sonar_trk.shp)

ArcMap Document:

OFR_2005-1346.mxd - ArcMap document containing all data layers described above.

\section{Data Catalog}

Table 1. Data Catalog.

\begin{tabular}{|c|c|c|c|c|}
\hline File Description $^{1}$ & File Name & File Format & File Location & Download \\
\hline Bathymetry & bathy_grd & $\begin{array}{l}\text { ESRI Grid } 32 \text { bit } \\
\text { floating point }\end{array}$ & arcgis/bathy & bathy_grd.zip \\
\hline $\begin{array}{l}\text { Bathymetric } \\
\text { Hillshade }\end{array}$ & bathy_hillsh & $\begin{array}{l}\text { ESRI Grid } 16 \text { bit } \\
\text { integer }\end{array}$ & arcgis/bathy & bathy_hillsh.zip \\
\hline $\begin{array}{l}\text { Bathymetric } \\
\text { Contours ( } 1 \text { meter) }\end{array}$ & don_1m & $\begin{array}{l}\text { ESRI Shapefile } \\
\text { Polyline }\end{array}$ & arcgis/bathy & con_1m.zip \\
\hline $\begin{array}{l}\text { Sidescan-Sonar } \\
\text { Mosaic }\end{array}$ & mosaic.tif & TIFF 8 bit integer & arcgis/mosaic & mosaic.tif \\
\hline
\end{tabular}




\begin{tabular}{|c|c|c|c|c|}
\hline $\begin{array}{l}\text { Sidescan-Sonar } \\
\text { Mosaic }\end{array}$ & mosaic_comp.sid & MrSID Compression & arcgis/mosaic & mosaic_sid.zip \\
\hline $\begin{array}{l}\text { NGDC Coastal } \\
\text { Relief Model }\end{array}$ & ngdc_crm & TIFF 8 bit integer & arcgis/ngdc & ngdc_crm.zip \\
\hline $\begin{array}{l}\text { Onshore Borehole } \\
\text { Locations }\end{array}$ & boreholes & ESRI Shapefile Point & arcgis/onshore & boreholes.zip \\
\hline Hydrography & gshydd & $\begin{array}{l}\text { ESRI Shapefile } \\
\text { Polyline }\end{array}$ & arcgis/onshore & gshydd.zip \\
\hline $\begin{array}{l}\text { Onshore Contours: } \\
\text { Base of Quaternary }\end{array}$ & onshore_con & $\begin{array}{l}\text { ESRI Shapefile } \\
\text { Polyline }\end{array}$ & arcgis/onshore & onshore_con.zip \\
\hline $\begin{array}{l}\text { Rotasonic Core } \\
\text { Locations }\end{array}$ & rotasonic & ESRI Shapefile Point & arcgis/onshore & rotasonic.zip \\
\hline $\begin{array}{l}\text { Grab Sample } \\
\text { Locations }\end{array}$ & grabs & ESRI Shapefile Point & arcgis/samples & grabs.zip \\
\hline $\begin{array}{l}\text { Grain Size } \\
\text { Distribution }\end{array}$ & grainsize_poly & $\begin{array}{l}\text { ESRI Shapefile } \\
\text { Polyline }\end{array}$ & arcgis/samples & grainsize_poly.zip \\
\hline $\begin{array}{l}\text { Seismic Reflection } \\
\text { Profiles }\end{array}$ & seisimag & JPEG image format & arcgis/seisimag & seisimag.zip \\
\hline Paleochannels & paleoch_grd & $\begin{array}{l}\text { ESRI Grid } 32 \text { bit } \\
\text { floating point }\end{array}$ & arcgis/seismic_srf & paleoch_grd.zip \\
\hline $\begin{array}{l}\text { Modern Sediment } \\
\text { Thickness }\end{array}$ & sedthick_grd & $\begin{array}{l}\text { ESRI Grid } 32 \text { bit } \\
\text { floating point }\end{array}$ & arcgis/seismic_srf & sedthick_grd.zip \\
\hline $\begin{array}{l}\text { Transgressive } \\
\text { Surface }\end{array}$ & transgr_grd & $\begin{array}{l}\text { ESRI Grid } 32 \text { bit } \\
\text { floating point }\end{array}$ & arcgis/seismic_srf & transgr_grd.zip \\
\hline Ridge Crests & ridge_crests & $\begin{array}{l}\text { ESRI Shapefile } \\
\text { Polyline }\end{array}$ & arcgis/sf_env & ridge_crests.zip \\
\hline $\begin{array}{l}\text { Sea Floor } \\
\text { Environments }\end{array}$ & seafloorenv & $\begin{array}{l}\text { ESRI Shapefile } \\
\text { Polygon }\end{array}$ & arcgis/sf_env & seafloorenv.zip \\
\hline Sea Floor Geology & surf_geol & $\begin{array}{l}\text { ESRI Shapefile } \\
\text { Polygon }\end{array}$ & arcgis/sf_env & surf_geol.zip \\
\hline $\begin{array}{l}\text { Swath Bathymetry } \\
\text { Tracklines }\end{array}$ & bathy_trk & $\begin{array}{l}\text { ESRI Shapefile } \\
\text { Polyline }\end{array}$ & arcgis/tracklines & bathy_trk.zip \\
\hline Boomer Shot Point & boomer_sht & ESRI Shapefile Point & arcgis/tracklines & boomer_sht.zip \\
\hline Boomer Tracklines & boomer_trk & $\begin{array}{l}\text { ESRI Shapefile } \\
\text { Polyline }\end{array}$ & arcgis/tracklines & boomer_trk.zip \\
\hline Chirp Shot Point & chirp_sht & ESRI Shapefile Point & arcgis/tracklines & chirp_sht.zip \\
\hline Chirp Tracklines & chirp_trk & $\begin{array}{l}\text { ESRI Shapefile } \\
\text { Polyline }\end{array}$ & arcgis/tracklines & chirp_trk.zip \\
\hline $\begin{array}{l}\text { Sidescan-Sonar } \\
\text { Tracklines }\end{array}$ & sonar_trk & $\begin{array}{l}\text { ESRI Shapefile } \\
\text { Polyline }\end{array}$ & arcgis/tracklines & sonar_trk.zip \\
\hline
\end{tabular}

\section{References Cited}

Baldwin, W.E., Morton, R.A., Denny, J.F., Dadisman, S.V., Schwab, W.C., Gayest, P.T., and Driscoll, N.W., 2004, Maps Showing the Stratigraphic Framework of South Carolina's Long Bay from Little River to Winyah Bay, USGS Open-File Report 2004-1013.

Baldwin, W.E., Morton, R.A., Putney, T.R., Katuna, M.P., Harris, M.S., Gayes, P.T., Driscoll, N.W., Schwab, W.C., and Denny, J.F., 2006, Migration of the Pee Dee River system inferred from ancestral paleochannels underlying the South Carolina Grand Strand and Long Bay inner shelf, Geological Society of America Bulletin, May/June 2006, p. 533-549 
Denny, J.F., Baldwin, W.E., Schwab, W.C., Gayes, P.T., Morton, R., and Driscoll, N.W. Modern Sediment Distribution on the inner shelf of South Carolina's Long Bay from Little River to Winyah Bay, 2006, USGS Open-File Report 2005-1345.

Denny, J.F., Baldwin, W.C., Schwab, W.C., Warner, J.C., and DaVoe M.R., 2005, South Carolina Coastal Erosion Study, USGS Fact Sheet 2005-3041.

\section{Acknowledgements}

Funding for this research was provided by the U.S. Geological Survey (USGS) Coastal and Marine Geology Program and the South Carolina Sea Grant Consortium (SCSGC). Assistance in the field was provided by Bill Danforth, Tom O'Brien, Dave Foster, Dave Nichols, Barry Irwin, Chuck Worley, Shawn Dadisman, VeeAnn Cross and Walter Barnhardt from the USGS, and Captain Richard Goldberg, Liz Johnstone, Neil Gielstra and Jamie Phillips from Coastal Carolina University. This manuscript benefited from reviews by VeeAnn Cross and Brian Andrews. 


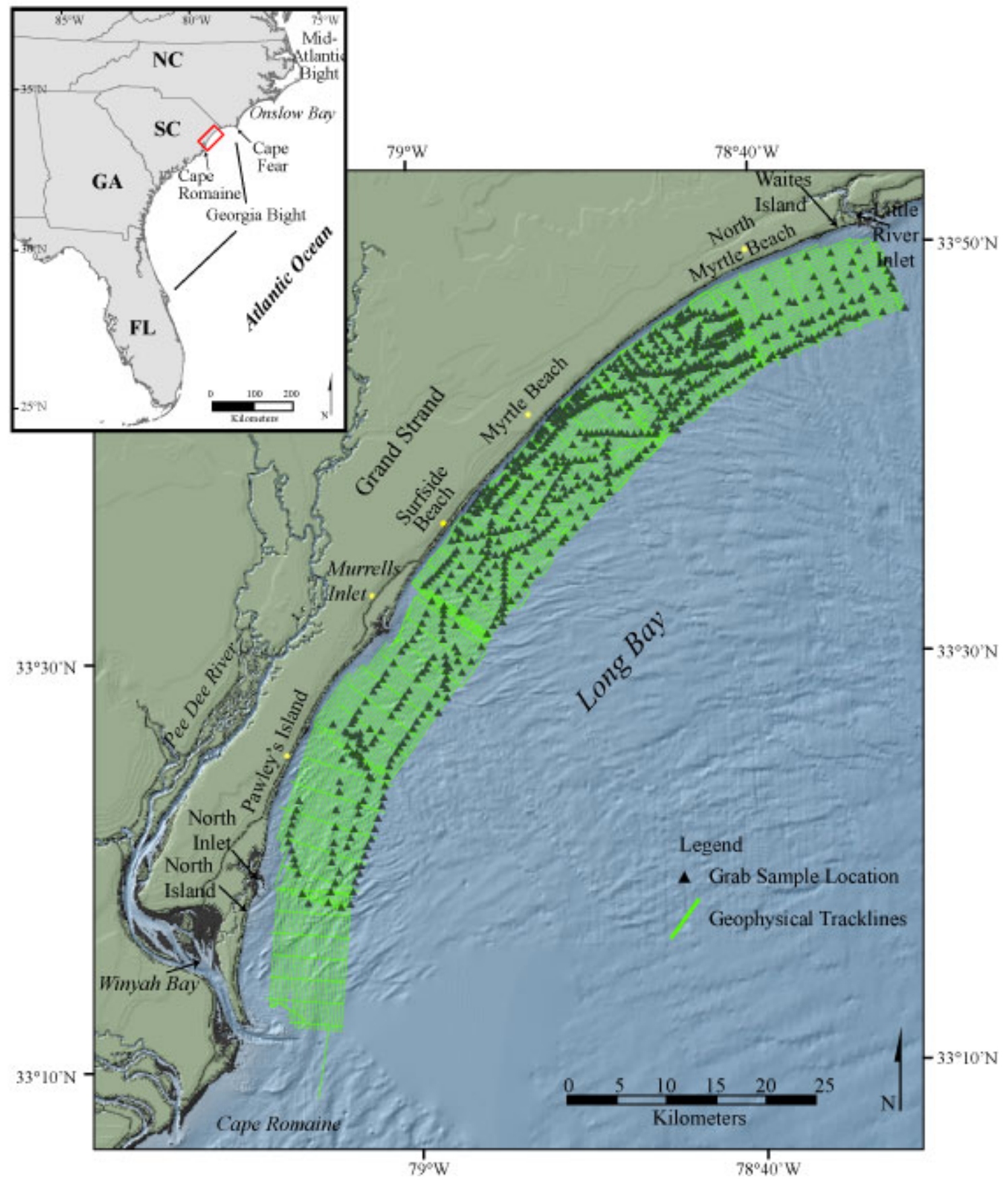

Figure 1. Map showing the location of the survey area offshore of South Carolina between Little River Inlet to the north and Winyah Bay to the south. Geophysical tracklines and sample locations are displayed. 